\title{
USING THE IMPORTANT PERFORMANCE ANALYSIS TO IMPROVE PRODUCT AND SERVICE ATTRIBUTE PERFORMANCE IN REGIONAL-OWNED ENTERPRISE
}

\author{
Muchamad Bachtiar ${ }^{*}$, Raden Isma Anggraini*), and Fithriyyah Shalihati ${ }^{*}$ \\ *) School of Business, IPB University \\ Jl. Pajajaran, Bogor 16151
}

\begin{abstract}
This study aimed to analyze the performance level and importance level according to customer perceptions as well as the priority of product and service attribute improvement. The data were analyzed using descriptive analysis of the Importance Performance Analysis (IPA) and Customer Service Index (CSI) approach with 1980 respondents out of 157,270 customers selected through Cluster Stratified and Systematical Unproporsional Sampling (CSUS) technique. The result showed that there was no product attribute with significantly low performance. It was supported by the CSI result with a value of 0.74 , which meant SATISFACTORY or VERY GOOD. However, there were still negative gaps between the performance level and importance level, with an average value of 0.36 . Product attribute (P2) water supply quality, (P3) water continuity, (P4, P5, and P6) water quality were quite a concern. This study also found a product attribute with a positive gap in (P7)water quality (sediment), which meant that this ROE could reallocate its utilized resources to improve other product attributes of concern. In terms of service attributes, there was no significant attribute that needed an immediate follow-up. It was supported by the overall CSI score of 0.76 , which meant SATISFACTORY or VERY GOOD. Even so, service attributes were important and deserved attention in the aspects of (J2) bill payment process, (J6) the capability of call center officers and (J7) social media admins, and (J10) dispute settlement with customers. Five service attributes, which were (J1) administrative services, (J3) complaint services, (J4) fairness to obtain services, (J5) the capability of customer service officers, and (J11) service interruption information, were recommended to be reallocated to other service attributes that were more important.
\end{abstract}

Keywords: customer satisfaction, Customer Satisfaction Index (CSI), Importance Performance Analysis (IPA), regional-owned enterprise

\begin{abstract}
Abstrak: Tujuan penelitian ini adalah menganalisis tingkat kinerja dan tingkat kepentingan menurut persepsi pelanggan serta prioritas perbaikan atribut pada layanan produk dan jasa. Metode analisis data dilakukan menggunakan analisis dekriptif metode Importance Performance Analysis (IPA) dan Customer Service Index (CSI) terhadap 1980 responden dari 157.270 populasi pelanggan dengan Teknik Cluster Stratified and Systematical Unproporsional Sampling (CSUS). Hasil penelitian menunjukkan tidak ada atribut produk yang sangat signifikan dengan kinerja rendah yang didukung hasil CSI dengan nilai 0.74 yang berarti "PUAS". Akan tetapi masih terdapat kesenjangan negatif antara tingkat kinerja dibandingkan tingkat kepentingan dengan nilai rata rata -0.36. Atribut produk (P2) kualitas pengaliran air, (P3) kontinuitas air, (P4, P5 dan P6) kualitas air cukup menjadi perhatian. Pada atribut produk juga ditemukan gap positif pada (P7) kualitas air: endapan yang berarti BUMD ini dapat merealokasi sumberdaya terpakai untuk kepentingan memperbaiki atribut produk lain yang menjadi perhatian. Sedangkan pada atribut jasa tidak terdapat atribut yang signifikan penting untuk harus ditindaklanjuti segera. Nilai skor kepuasan pelanggan juga menunjukkan hal inikkan 0.76 yang berarti "puas" Walaupun demikian, atribut jasa penting dan layak mendapat perhatian pada aspek (J2) pembayaran tagihan. (J6) kemampuan petugas call center dan (J7) admin media sosial, serta (J10) penyelesaian perselisihan dengan pelanggan. Pada atribut jasa direkomendasikan untuk merealokasi sumberdaya (J1) pelayanan administrasi, (J3) pelayanan aduan, (J4) Keadilan mendapatkan layanan, (J5) kemampuan petugas pelayanan pelanggan dan (J11) informasi gangguan pelayanan pada atribut jasa yang lain yang lebih penting.
\end{abstract}

Kata kunci: BUMD, Customer Satisfaction Index (CSI), Importance Performance Analysis (IPA), kepuasan pelanggan

\footnotetext{
${ }^{1}$ Corresponding author:

Email: muchamadbachtiar@apps.ipb.ac.id
} 


\section{INTRODUCTION}

BUMD XYZ generally had two functions, namely economic and social function. Economic function refers to improving service capability and completing other duties by managing the enterprise well based on its economic principles. Social function refers to fulfilling the needs of all society by imposing drinking water supply tariff adjusted to the customers' condition and location, as well as the subsidized customers. Feedbacks from the stakeholders are needed to achieve the optimal performance of the two functions. One of the stakeholders considered highly important is the customer. Measures usually conducted to view the feedback from the customers are surveying satisfaction on the products and services, as well as observing the important attributes in the customer perception compared to the performance.

According to Amir (2005), customer satisfaction becomes the main objective of the marketers or service providers, so that companies attempt to understand the wants of their customers on their products and services. Based on Rangkuti (2006), it is defined as customer response on the gap between the importance level before consumption and the actual performance perceived by customers after consumption. It will influence customer perception of the products and services offered (Rangkuti, 2006). Besides, Oliver (1997) stated that it could be made as an after-sales evaluation material in which the perception of the product/service alternative performance can meet/ exceed the buyer expectation. In the manufacturing market, the importance of assessing and managing customer satisfaction is widely recognized (Tikkanen et al. 2000). It was even empirically proven that other than quality, customer satisfaction has a direct effect on financial performance by enhancing customer loyalty, reducing price elasticity, increasing cross-selling, and improving words of mouth promotion (Anderson et al. 1994; Eklo et al. 1999; Ittner and Larcker, 1998).

Every company is limited by its resources so that it is necessary to identify the critical factors determining customer satisfaction level and loyalty. Important Performance Analysis (IPA) is an effective method to determine the priority in resource utilization. It can analyze the quality attributes in two dimensions, namely performance level (satisfaction) and importance level for the customers. The evaluation of attributes in these two dimensions is then combined into a matrix enabling the company to identify the major drivers of satisfaction to formulate the improvement priority and find the "possible overkill" and "acceptable" area. (Matzler et al. 2004). IPA is considered as a simple but effective method (Hansen and Bush, 1999)

There had been a study carried out in 2018 with the total respondents of 1980 customers, which showed the satisfaction level on products and services with the value of SATISFACTORY. Studies on customer satisfaction were continuously undertaken as a form of the company's performance transparency, as well as to see multiple performance areas based on the improvement priority. Therefore, a similar survey is deemed essential to conduct annually so that the company knows whether there is an improvement in customer satisfaction of the company services. In this case, it was in BUMD XYZ of Bogor City. Customer Satisfaction Survey (SKP) was conducted on two types of service, namely product performance and service performance. The assessment on the product performance (attributes) covered nine variables, while on the service performance (attributes) covered eleven variables. In the previous studies, there had been no information concerning the change in the satisfaction level of the surveyed respondents. Also, the direction of change in customer perception on performance and service change level (products and services). This study aimed to obtain the bases of consideration and references in planning and decision making aimed to improve customer satisfaction. The previous study had utilized the Customer Satisfaction Index (CSI) and IPA method. Thus, the same methods could be utilized again so that the satisfaction (performance) and importance level of product and service attributes from the previous study could be compared to the latest one.

The objectives of this study were as follows: Identify the customer satisfaction level of BUMD XYZ; Identify the customer perception of the performance and importance level of product and service attributes of BUMD XYZ; Obtain the direction of change in customer perception on product and service attributes based on the performance and importance level in 2018 and 2019; and Provide recommendations according to the priority scale to improve the product and service performance of BUMD XYZ and optimize the customer satisfaction level. 


\section{METHODS}

This study was conducted in Bogor City from November to December 2019. The period was selected to obtain a close-to-intact overview of one year, as well as to gain the right comparison with the period of the previous study (the same period of 2018). The data and information used in this study were qualitative and quantitative data collected through a survey (questionnaire). The types of data used were primary and secondary data. Primary data were obtained from the respondents through structured interviews using a questionnaire, while secondary data were acquired from various relevant sources.

The sampling and respondent selection method was based on the previous study, which used Cluster Stratified and Systematical Unproporsional Sampling (CSUS) with seventeen tariff categories being made into a matrix with six supply zones. The number of respondents surveyed was 1980, with old customers (2018) amounted to 30\% (594 respondents), and new respondents (2019) amounted to 60\% (1386 respondents).

The data processing and analysis methods utilized in this study were qualitative and quantitative analysis. Qualitative analysis was carried out descriptively to analyzed customer characteristics using a structured questionnaire containing demographic information and others. Quantitative analysis was applied to evaluate the performance and importance level of the attributes for the respondents by using CSI and IPA or Biiplot analysis.

Descriptive analysis was used in analyzing customer characteristics and behavior. It is an analysis related to the data collection and presentation so that they provide beneficial information. It was conducted by tabulating the questionnaire results manually. The measures of this method were as follows: Measures of central tendency: Mean, median, and mode; Measures of variation: Range, variance, and coefficient of variation; Rate, ratio, and proportion; Percentage analysis.

\section{Customer Satisfaction Index (CSI)}

Providing value and satisfaction for the customers is highly crucial in company competitiveness improvement (Kotler and Armstrong, 1997; Weitz and
Jap, 1995). One of the methods most frequently used is CSI. It is a structural model based on the theory that factors like quality, value, customer expectation, and company image creates customer satisfaction (Fornell et al. 1996). It was harnessed in various industries, such as motorcycle (Terblanche and Boshoff, 2010) and tourism (Deng et al. 2013). It was also used to measure the customer satisfaction level of BUMD XYZ. It reflects the customer satisfaction level comprehensively, by considering the importance level and performance value from the customers, upon the attributes of products and services used by the customers. The satisfaction level is calculated from the weight of each average value of performance-and-importance level of the attributes. According to Strattford (2004), the stages of measurement in CSI are as follows: Measure the importance level and customer satisfaction level on the attributes affecting customer satisfaction using the Likert scale; Calculate the average score of importance and satisfaction of each attribute; Calculate the importance weighting factor obtained from the score of each attribute divided by the total importance of all attributes; Calculate the weighted score obtained from the multiplication of importance weighting factor with the score of satisfaction of each attribute; Calculate the weighted average obtained from the sum of the weighted score of all attributes; Calculate the customer satisfaction index obtained from the division of weighted average against the maximum scale.

Based on the stages above, there will be found the index value ranging between $0.00-0.34$, which means UNSATISFACTORY; $0.35-0.50$, which means LESS SATISFACTORY; 0.51-0.65, which means FAIRLY SATISFACTORY; 0.66-0.80, which means SATISFACTORY; and 0.81-1.00, which means VERY SATISFACTORY.

\section{Service Quality (SERVQUAL) Dimensions}

Zeithaml et al. (1990) explained SERVQUAL as a model concept, also known as gap analysis model, related to the customer satisfaction model referring to the extent of the company's performance in meeting the expectation on an attribute until the positive perception on the service quality is created. It has five dimensions that if they are applied simultaneously, they will be able to develop an excellent-quality and satisfactory service. Those five dimensions are as follows: Tangibles (The ability to show existence to the 
external party, covering the appearance and capability of the physical facilities and infrastructures, as well as the surrounding conditions); Reliability (The ability to provide immediate, accurate, and satisfactory services according to customer expectation through punctuality, optimal services, sympathetic attitude, and high accuracy); Responsiveness (The ability to assist and provide quick and right services through the delivery of clear information); Assurance (company knowledge and ability to grow customer trust in the company services); Empathy (Provide a sincere and personal assurance for the customers by trying to understand their wants).

\section{Importance Performance Analysis (IPA)}

IPA is a model used to analyze the extent of of customer satisfaction and often called as satisfaction level or importance level analysis. On its development, IPA is widely used in various sectors like tourism management (Boley et al. 2017), healthcare services (Lee et al. 2015); education (Mcleay et al. 2017), laboratory equipments (Ferreira and Fernandes, 2015), and others. IPA analysis is utilized to identify at what level the product and service is running. The importance level can be defined as how customers expect the products and services. Meanwhile, satisfaction level can be defined as how customers perceive the actual performance of the products and services. The outputs from IPA are presented in the form of the Importance-Performance Matrix. IPA analysis is also utilized to analyze the performance of each attribute. The attributes in this analysis used SERVQUAL dimensions. Hence, the weight of satisfaction and importance of each attribute was acquired based on the Likert scale.

Table 1 For-level assessment scale used (Likert scale)

\begin{tabular}{lcc}
\hline \multicolumn{1}{c}{$\begin{array}{c}\text { Importance } \\
\text { assessment }\end{array}$} & $\begin{array}{c}\text { Performance } \\
\text { assessment }\end{array}$ & Weight \\
\hline Very important & Very good & 4 \\
Important & Good & 3 \\
Less important & Fair & 2 \\
Unimportant & Poor & 1 \\
\hline
\end{tabular}

Based on the assessment of importance and satisfaction level on products and services, there will be generated the calculation on its suitability and performance level. With this suitability level, there will be obtained the order of priority in the improvement of factors influencing product/service satisfaction. As this study categorized respondents into two, BUMD XYZ could improve the attributes that have not been satisfactory for the customers and maintain the satisfactory ones, through the inputs from the two types of respondents.

The manifestation of customer satisfaction of BUMD $\mathrm{XYZ}$ was inevitable from its products and services. In other words, the products and services of BUMD XYZ must be in line with its customer needs. This study categorized the respondents into two, namely customers 2018 (old customers) and customers 2019 (new customers). Comparison analysis regarding the performance of important attributes was carried out on customers 2018 and customers 2019. This analysis would show which attributes experienced no change, a decrease, and an increase so that the results could be evaluated.

This study also performed a survey on the customers who had not participated in such a survey (not customers 2018). This survey was done to evaluate the performance of product and service attributes of BUMD XYZ according to the customer assessment and perception. Through this evaluation, the customer satisfaction level on the services of BUMD XYZ, as well as the attributes that became the benchmarks of customer satisfaction, could be identified. Inputs from the respondents would enable BUMD XYZ to make an improvement on the attributes that had not been satisfactory for the customers, as well as maintain the satisfactory ones so that the customer satisfaction level of BUMD XYZ could be formulated. Figure 1 presents the conceptual framework of this study.

\section{RESULTS}

\section{Customer Satisfaction Index (CSI)}

In general, the customer satisfaction level on product and service attributes was at the "satisfactory" level with the CSI of respectively 0.74 for product and 0.76 for service. Table 2 shows that there was still a gap between the performance (actual condition) and importance level (future expectation) with the average gap value of 0.36. The highest gap existed in ZAMP \& KASM (P9) product element, with the average performance level value of 2.66, while its average importance level value was 3.11. These meant that there happened a gap between the actual condition perceived and the 
ideal condition expected by the customers by 0,45 . BUMD XYZ recorded a performance that exceeded the expectation/importance level in P7 (water quality: sediment).

BUMD XYZ had a better average gap value in service attributes than in product attributes with the gap value of 0,33 . The highest gap occurred in the element of compensation on service interruption (J8) with the gap value of 0.88 , while the lowest gap value was in $\mathrm{J} 10$ (dispute settlement with the customers). The complete CSI of BUMD XYZ can be viewed in Table 2 (product attributes) and Table 3 (service attributes).

\section{Product Attributes}

The gap between the actual condition (performance) and the future expectation (importance level) in product attributes was quite high and represented almost all product attributes with various values. BUMD XYZ must attempt to improve by carrying out the priority scale. Figure 2 depicts the direction on performance improvement priority for product attributes.

The above quadrant visualizes the analysis results, in which five of the nine elements related to the water supply quality (P2), water supply continuity (P3), and water quality (P4, P5, and P6) were in quadrant I. These meant that the performance of the five elements was worth maintaining as they met the customer expectation. Meanwhile, one of the nine elements related to water quality (sediment) (P7) was in quadrant II. Quadrant II needs more attention according to the objective of the IPA of optimizing the satisfaction level with limited resources. Thus, BUMD XYZ management must reallocate its resources for P7 performance to the other product attributes in quadrant I. The other three elements (P1, P8, and P9) belonged to quadrant III which is the low priority. With no product attribute belonged to quadrant IV, this indicated a suitability with the CSI value categorized as SATISFACTORY.

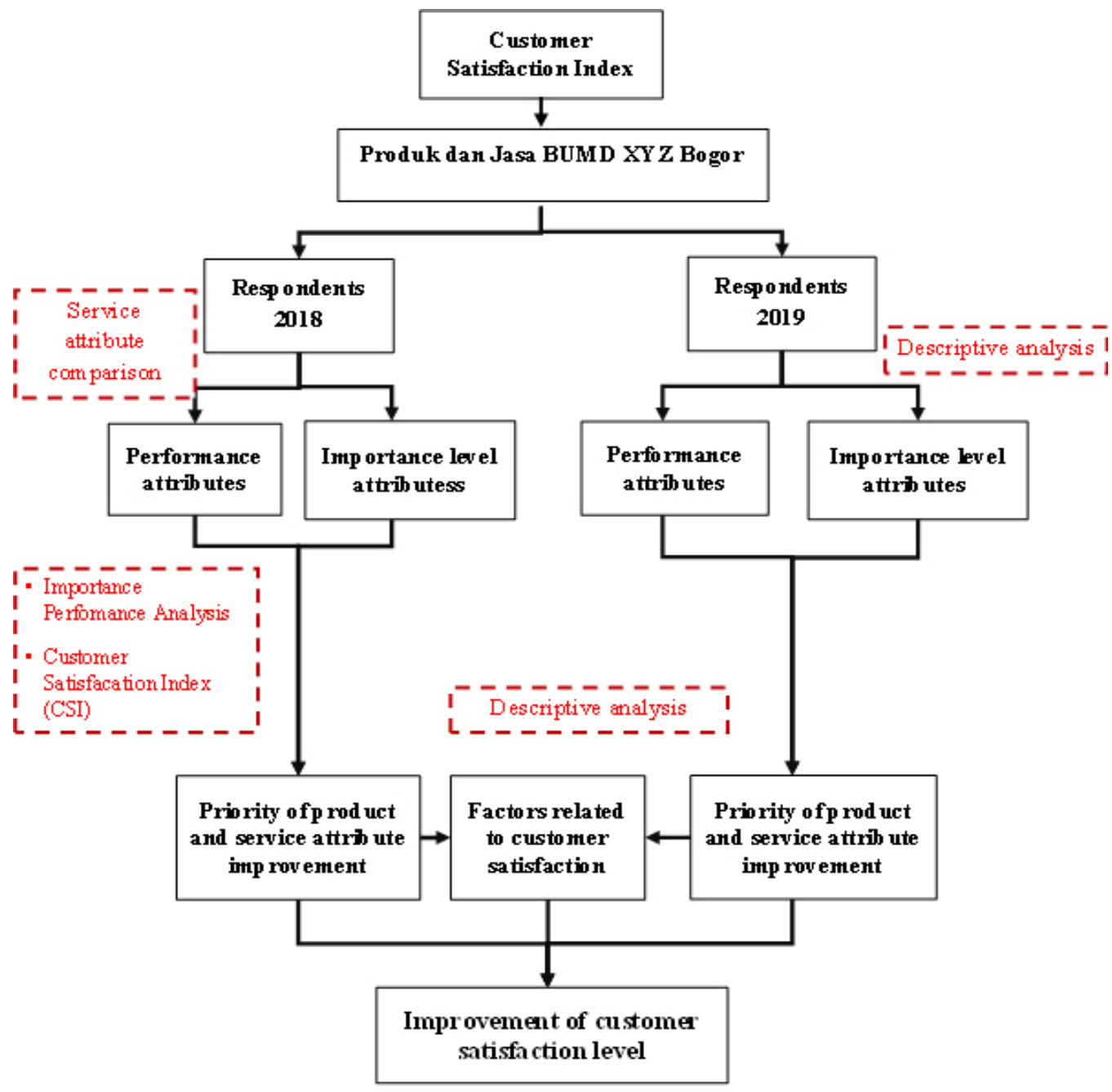

Figure 1. Research framework 
Table 2.CSI of BUMD XYZ on product attributes

\begin{tabular}{|c|c|c|c|c|c|c|c|}
\hline Type of service & Element & $\begin{array}{c}\text { Actual } \\
\text { condition } \\
\text { (performance) }\end{array}$ & $\begin{array}{l}\text { Future expectation } \\
\text { (importance level) }\end{array}$ & Gap & WF & WS & CSI \\
\hline Water supply quality in the dry season & $\mathrm{P} 1$ & 2.9 & 3.33 & 0.43 & 11.11 & 32.22 & \multirow{12}{*}{$\begin{array}{c}0.74 \\
\text { (Satis- } \\
\text { factory) }\end{array}$} \\
\hline Water supply quality in the rainy season & $\mathrm{P} 2$ & 3.02 & 3.38 & 0.36 & 11.29 & 34.10 & \\
\hline Water supply continuity & $\mathrm{P} 3$ & 2.98 & 3.40 & 0.42 & 11.36 & 33.86 & \\
\hline Water quality: Free of bacteria and taste & $\mathrm{P} 4$ & 2.98 & 3.40 & 0.42 & 11.36 & 33.86 & \\
\hline Water quality: Purity & P5 & 2.98 & 3.40 & 0.42 & 11.36 & 33.86 & \\
\hline Water quality: Smell & P6 & 2.98 & 3.40 & 0.42 & 11.36 & 33.86 & \\
\hline Water quality: Sediment & $\mathrm{P} 7$ & 3.33 & 3.32 & -0.01 & 11.10 & 36.96 & \\
\hline $\begin{array}{l}\text { Water quality: Water meter replacement/ } \\
\text { calibration }\end{array}$ & P8 & 2.83 & 3.19 & 0.36 & 10.66 & 30.17 & \\
\hline $\begin{array}{l}\text { Product: ZAMP (Prime Drinking Water } \\
\text { Zone) \& KASM (Ready-to-Drink Water } \\
\text { Tap) }\end{array}$ & P9 & 2.66 & 3.11 & 0.45 & 10.39 & 27.62 & \\
\hline Total & 26.66 & 29.94 & 3.28 & 100.00 & 296.53 & & \\
\hline Range & & & & & 4 & & \\
\hline Average & 2.96 & 3.33 & 0.36 & 11.11 & 32.95 & & \\
\hline
\end{tabular}

Table 3.CSI of BUMD XYZ on service attributes

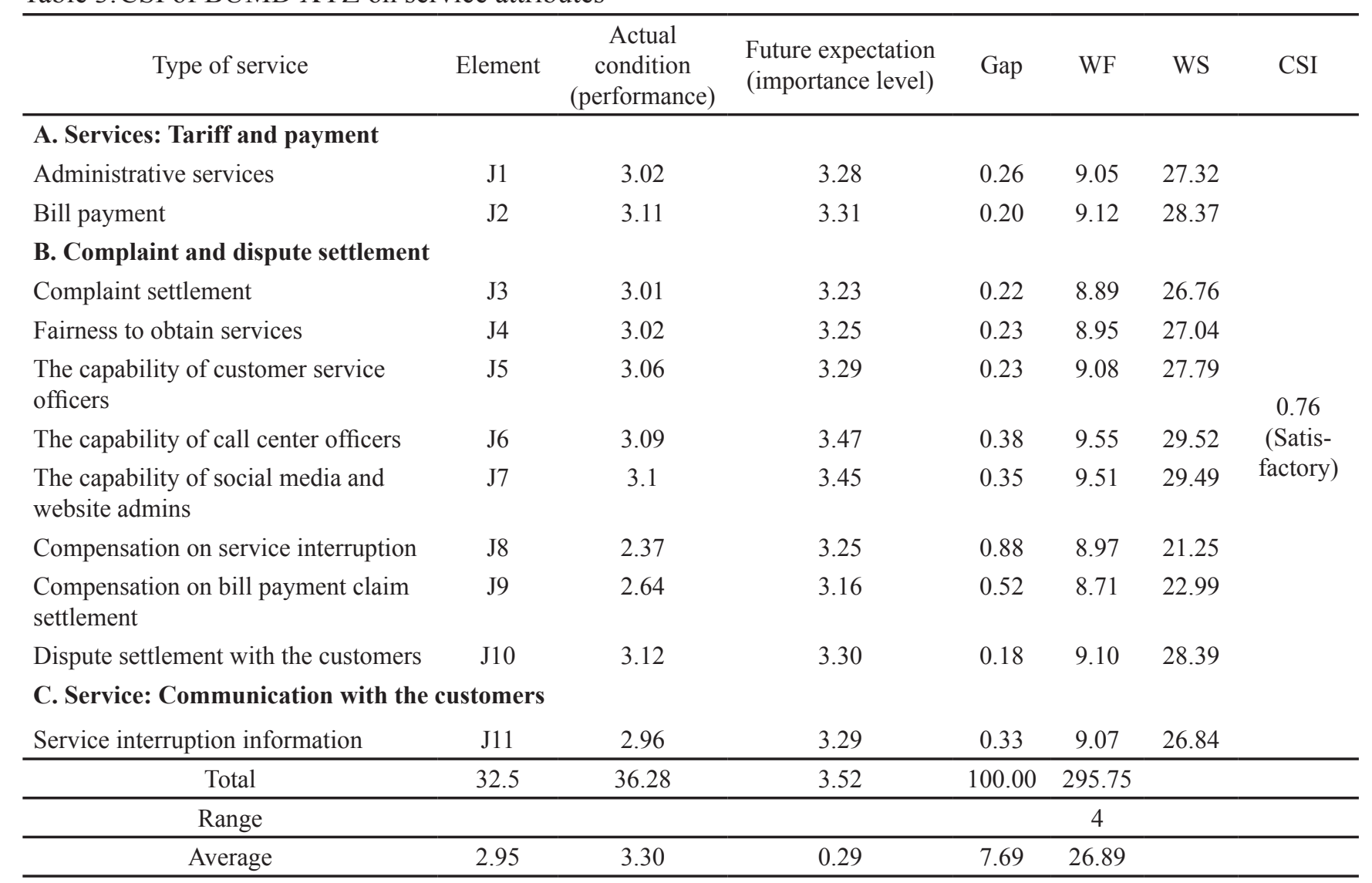

\section{Service Attributes}

The gap level in service attributes occurred in all attributes with various values, although it overall showed a better value than in product attributes. Based on the performance level and importance level of service attributes of BUMD XYZ in 2019, the direction on performance improvement priority is portrayed in Figure 3. The vast number of customer complaints on the service attribute performance of BUMD XYZ considered necessary by the customers had been successfully and satisfactorily handled. The attribute 
was included in quadrant $\mathrm{I}$, in which the performance of attributes within it was worth maintaining. The service attributes belonged to this quadrant were $\mathrm{J} 2$ (bill payment), J6 (the capability of call center officers), $\mathrm{J} 7$ (the capability of social media and website admins), and J10 (dispute settlement with the customers).

In quadrant II, there were five elements, namely J1, J3, $\mathrm{J} 4$, J5, and J11. This meant that administrative services, complaint settlement, fairness to obtain services, customer service officers, and service interruption information were considered less important but had been performed well so that they were considered excessive. BUMD XYZ was directed to reallocate its existing resources to pay more attention to service attributes in quadrant I. Two elements belonged to quadrant III, namely compensation on service interruption (J8) and compensation on bill payment claim (J9). These elements were considered less important and their performance was ordinary, thus considered less satisfactory. The direction for elements in this quadrant III was just to be ignored due to their low priority. On the other hand, no element belonged to quadrant IV. In other words, there was no element considered important but unsatisfactory, as supported by the result of CSI at the level of SATISFACTORY.

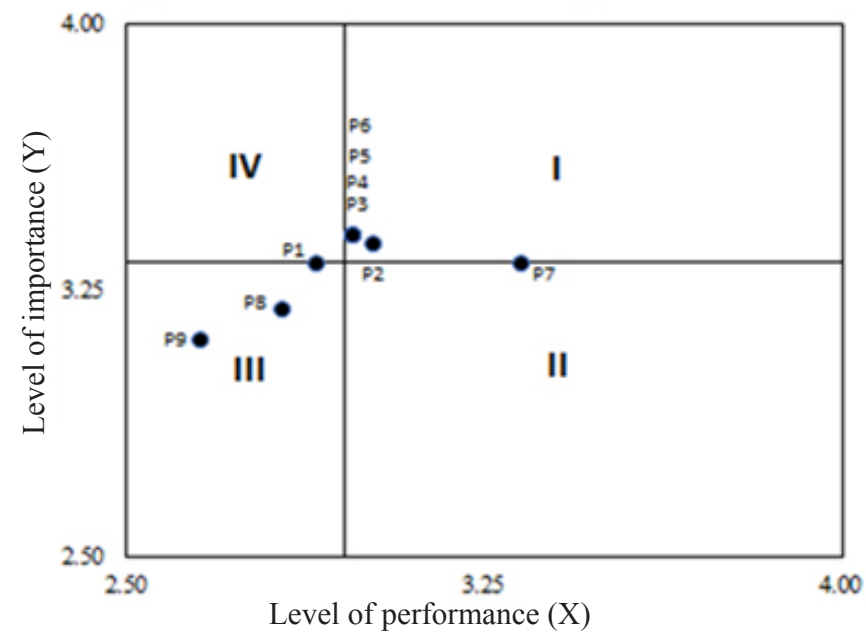

Figure 2. IPA matrix or quadrant of direction on performance improvement priority for product attributes of BUMD XYZ

\section{Customer Satisfaction Comparison between 2018 and 2019}

Customer satisfaction comparison was conveyed to find out the result of performance carried out for a year and as a material for review whether BUMD XYZ had satisfied customer expectations or still need to improve its performance. It was conveyed in the form of table containing elements, their positions in the quadrant in 2018, and their positions in the quadrant in 2019 so that the comparison results are visible. The colors of the numbers indicating the quadrants hold the following meanings: Blue, it means to maintain: experienced an increase; Red, it means to focus on improvement: experienced a decrease; Black, it means no change in performance; Green, it means to focus on attention: attribute efficiency; Yellow, it means not a priority.

The element positions in the quadrants hold the following meanings: Position I means that the performance had been satisfactory, and it was considered important by the customers so that it must be maintained; Position II means that the performance had been satisfactory, but it was considered less important by the customers, thus regarded as excessive; Position III means that the performance was unsatisfactory, and it was considered less important by the customers so that it belonged to the low priority to be improved; Position IV means that the performance was unsatisfactory, but it was considered important by the customers so that it belonged to the main priority to be immediately improved.

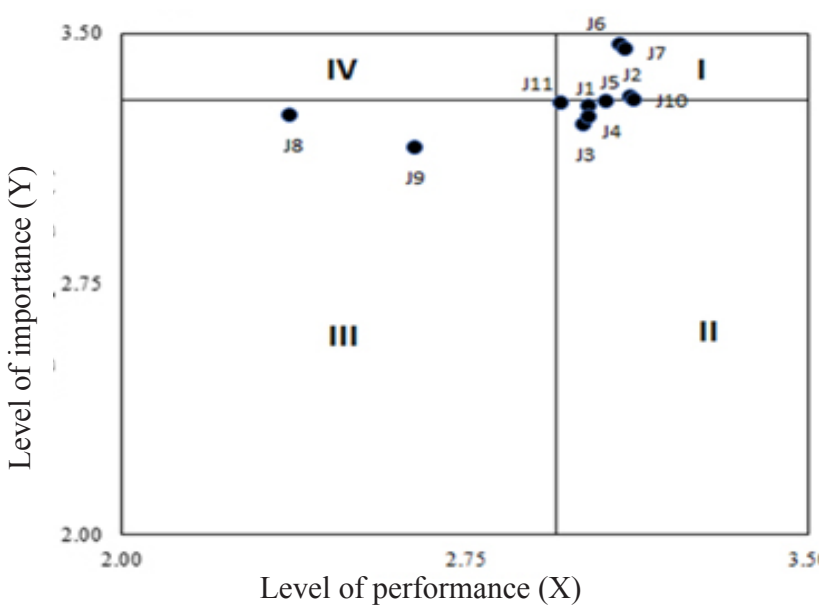

Figure 3. Quadrant of direction on performance improvement priority for service attributes of BUMD XYZ 


\section{Comparison of Customer Satisfaction on Product Attributes between 2018 and 2019}

Product attribute performance generally showed an improvement in several elements as shown in Table 5. The element of water supply quality in the rainy season and water quality related to purity (P2 and P5) experienced a performance improvement as they moved from quadrant IV to quadrant I. It meant that the customers kept considering them as important but their performance was unsatisfactory previously. In 2019, BUMD XYZ improved their performance so that the customers were satisfied.

Performance improvement data were also presented in water supply continuity and water quality related to assurance in free of bacteria and taste (P3 and P4) due to their movement from quadrant III to quadrant I. It meant that the customers previously considered them unimportant in 2018, unlike in 2019. BUMD XYZ also improved their performance to be better. The element of water quality related to water meter replacement/ calibration (P8) and ZAMP \& KASM (P9) product could bot be compared here as no customer satisfaction survey conducted related to these elements in 2018.

\section{Comparison of Customer Satisfaction on Service Attributes between 2018 and 2019}

The service performance data had shown an increase in several elements. As shown in Table 5, two elements experienced a performance improvement. The capability of social media and website admins (J7) experienced a move from quadrant III to quadrant I. This indicated that those elements in the previous year were considered less important, unlike in 2019. Besides, BUMD XYZ improved its performance to satisfy the customers in 2019. The element of dispute settlement with the customers (J10) also experienced a performance improvement as it moved from quadrant III to quadrant I. In other words, customers considered it less important in the previous year, unlike in 2019. BUMD XYZ also improved its performance in this aspect to satisfy the customers in 2019.

Table 4.Comparison of product attribute satisfaction between 2018 and 2019

\begin{tabular}{lcc}
\hline Element & Quadrant (2018) & Quadrant (2019) \\
\hline Water supply quality in the dry season (P1) & IV & III \\
Water supply quality in the rainy season (P2) & IV & I \\
Water supply continuity (P3) & III & I \\
Water quality: Free of bacteria and taste (P4) & III & IV \\
Water quality: Purity (P5) & I & I \\
Water quality: Smell (P6) & I \\
Water quality: Sediment (P7) & I \\
Water quality: Water meter replacement/calibration (P8) & II \\
Product: ZAMP (Prime Drinking Water Zone) \& KASM (Ready-to-Drink Water & III \\
Tap) (P9) & III
\end{tabular}

Table 5.Comparison of service attribute satisfaction between 2018 and 2019

\begin{tabular}{lcc}
\hline Element & Quadrant (2018) & Quadrant (2019) \\
\hline Administrative services (J1) & I & II \\
Bill payment (J2) & I & I \\
Complaint settlement (J3) & I & II \\
Fairness to obtain services (J4) & I & II \\
The capability of customer service officers (J5) & II & II \\
The capability of call center officers (J6) & III & I \\
The capability of social media and website admins (J7) & III & I \\
Compensation on service interruption (J8) & IV & III \\
Compensation on bill payment claim settlement (J9) & III & III \\
Dispute settlement with the customers (J10) & I \\
Service interruption information (J11) & I \\
\hline
\end{tabular}




\section{Managerial Implications}

Generally, there were four recommendations for BUMD XYZ. A sustainable survey needs to be conducted because the past trends are changed with the current trends. There is a change in consumer behavior so that the importance level perceived by customers changes from time to time. The other recommendation is that the management needs to focus on the elements contained in quadrant IV. Quadrant IV is the direction on performance improvement priority. The elements in this quadrant were the main priorities according to the customers so that a performance improvement must be able to meet the customer expectations. The result of the IPA matrix showed that there was no element contained in quadrant IV. Therefore, the next priority was in quadrant I. The other aspects that needed attention were elements experiencing a decline in performance, both in product and service attributes. BUMD XYZ could focus on the elements moving from quadrant II to quadrant I. Regarding the elements moving from quadrant I to quadrant II, BUMD XYZ could reallocate its resources (money, energy, time, etc.) to improve the performance of the other elements. However, the performance of those elements needs to be maintained so that it would not shift to another quadrant indicating a declining performance.

\section{Products}

Customer satisfaction improvement on the product attributes of BUMD XYZ could be undertaken by checking more intensively in the field to really see the water supply problems in Bogor City. The other ways that could be done are as follows: Enhance water resources that are the main products of BUMD $\mathrm{XYZ}$ in terms of quantity (flow) and quality (purity); Improve water supply and distribution system enabling BUMD XYZ to anticipate the impact of natural factors (seasonal); Ensure the supply continuity of water resources; Enhance the monitoring function on the aspects getting more attention from the customers.

\section{Service}

Customer satisfaction improvement on service attributes of BUMD XYZ could be conducted by identifying the communication networks often used by the customers, then maximizing them to inform the occurring interruption, such as communication media digitalization, apps, website, and social media. As a result, human resource training is required to elevate the expertise of using social media and call center officers. The customers also need an early warning concerning the activity plans of BUMD XYZ causing a supply interruption to the customers. BUMD XYZ needs to develop a better and broader information and communication system for the aspect of the capability of officers, development-and-socialization of new programs, and communication with the customers concerning interruption information and its compensation.

\section{CONCLUSIONS AND RECOMMENDATIONS}

\section{Conclusions}

The result of this study showed that there was no product attribute with significantly low performance as supported by the CSI value of 0.74 , meaning SATISFACTORY. However, there was still a negative gap between the performance level and the importance level, with an average value of 0.36 . Product attribute (P2) water supply quality, (P3) water supply continuity, ( $\mathrm{P} 4, \mathrm{P} 5$, and $\mathrm{P} 6)$ water quality were quite a concern. A positive gap was also discovered in product attribute (P7) water quality (sediment), which meant that BUMD XYZ could reallocate its utilized resources to improve other product attributes in concern. Likewise, there was no service attribute significantly important to be immediately followed up. It was in line with the customer satisfaction result with a score of 0.76 , meaning the customers perceived them as SATISFACTORY. However, service attributes deserved attention in the aspect of (J2) bill payment, (J6) the capability of call center officers, and (J7) social media admins, as well as (J10) dispute settlement with the customers. In terms of service attributes, it was recommended to reallocate the resources for (J1) administrative services, (J3) complaint services, (J4) fairness to obtain services, (J5) the capability of customer service officers, and (J11) service interruption information to the other more important service attributes..

\section{Recommendations}

There needs to be an annually sustainable survey so that BUMD XYZ could identify its customer satisfaction level and could keep improving the performance of its products and services. 


\section{REFERENCES}

Anderson EW, Fornell C, Lehmann DR. 1994. Customer satisfaction, market share and profitability: Findings from Sweden. Journal of Marketing 58(2): $112-122$.

Amir MT. 2005. Dinamika Pemasaran Jelajahi dan Rasakan. Jakarta: PT. Raja Grafindo Persada.

Boley BB, McGehee NG, Hammett AT. 2017. Importance-performance analysis (IPA) of sustainable tourism initiatives: the resident perspective. Tourism Management 58(2017): 66-77.

BUMD XYZ Kota Bogor. 2012. Buku Panduan Pelayanan. Bogor: BUMD XYZ.

BUMD XYZ Kota Bogor. 2019. Laporan Akhir Survey Kepuasan Pelanggan (SKP) BUMD XYZ Kota Bogor Tahun 2018. Bogor: BUMD XYZ.

Deng WJ, Yeh ML, Sung ML. 2013. A customer satisfaction index model for international tourist hotels: Integrating consumption emotions into the American Customer Satisfaction Index. International Journal of Hospitality Management 35: $133-140$

Fornell C et al. 1996. The American customer satisfaction index: Nature, purpose, and findings. Journal of Marketing 60(1996): 7-18.

Hansen E, Bush R J.1999. Understanding customer quality requirements. Model and application. Industrial Marketing Management 28(2): 119 130.

Ittner CD, Larcker DF. 1998. Arenon-financial measures leading indicators of financial performance? An analysis of customer satisfaction. Journal of Accounting Research 36(3): 1 - 35.

Kotler P, Armstrong G. 1997. Marketing: An Introduction. New York: Prentice-Hall.
Lee YC et al. 2015. Applying importance-performance analysis to patient safety culture. International Journal of Health Care Quality Assurance 28: 826-840.

Matzler K et al. 2004. The asymmetric relationship between attribute-level performance and overall customer satisfaction: a reconsideration of the importance-performance analysis. Industrial Marketing Management 33(4): 271-277.

McLeay F, Robson A, Yusoff M. 2017. New applications for importance-performance analysis (IPA) in higher education: understanding student satisfaction. Journal of Management Development 36(2017): 780-800.

Oliver RI. 1997. Statisfaction: A Behavioral Perspective on The Consumer. New York: Mc Graw Hill, Inc.

Rangkuti F. 2006. Measuring Customer Satisfaction: Gaining Customer Relationship Strategy Teknik Mengukur dan Strategi Meningkatkan Kepuasan Pelanggan \& Analisis Kasus PLN-JP. Jakarta: PT Gramedia Pustaka Utama.

Stratford. 2004. District Council Customer Satisfaction Index.https://www.stratford.gov.uk/doc/173436/ name/CSI\%20Results\%202004\%20Final\%20 Report.pdf/. [6 Apr 2020].

Terblanche NS, Boshoff C. 2010. Quality, value, satisfaction and loyalty amongst race groups: a study of customers in the South Africa fast food industry. South African Journal of Business Management 41(1): 1-9.

Weitz BA, Jap SD. 1995. Relationshipmarketing and distribution channels. Journal of the Academy of Marketing Science 23: 305-320.

Zeithaml VA, Parasuraman A, Berry LL. 1990. Delivering Quality Service: Balancing Customer Perceptions and Expectations. New York: The Free Press. 